\title{
Influence of Characteristics of the Local Government and the Audit Opinion by BPK Toward Disclosure of Financial Statements
}

\author{
Meyulinda Aviana Elim ${ }^{1}$, Thobias Elianus ${ }^{1}$, David Tomasowa ${ }^{1}$, \\ Deasy Susana Ndaparoka ${ }^{1}$ \\ \{meyulinda.aviana@gmail.com, thobiastomasowa@yahoo.com, david.tomasowa@pnk.ac.id, \\ deasyndaparoka22@gmail.com\} \\ Jurusan Akuntansi Politeknik Negeri Kupang ${ }^{1}$
}

\begin{abstract}
This research aimed to analyze the effect of characteristics of the local government and the Audit Opinion by BPK toward disclosure of the financial statements of local government district/town in NTT. Characteristics of local government can be measured from the wealth of the region /PAD, the level of dependency, Total assets, age of local government, the number of OPD and the size of the legislative. The samples in this research are the local government in one district and one city in the province of NTT. This research used a quantitative method with multiple linear regression analysis. The variables in this study are the wealth of the region/PAD, dependence level, the age of local government, number of OPD, the size of the legislature, the audit opinion of the BPK and disclosure of financial statements. From the results of testing 6 hypotheses, only 1 hypothesis can be accepted, namely the level of dependency.
\end{abstract}

Keywords: Disclosure, Financial Statements, Audit Opinion, Local Government

\section{Introduction}

Law Number 17 of 2003 concerning State Finances states that the President, Governors, Regents and Mayors are required to submit accountability reports on the implementation of the APBN / APBD in the form of financial reports containing at least a Balance Sheet, Realization of APBN / APBD Reports, Cash Flow Reports, and Notes to Financial statements [1]. An accounting standard is very important as a guide and guideline for the preparation of financial statements. Therefore, the government financial reports produced must follow the latest Government Accounting Standards, which are in accordance with Government Regulation No. 71 of 2010 [2].

The Basic Framework for the Preparation and Presentation of Financial Statements issued by the Indonesian Institute of Accountants (IAI) states that users of financial statements include investors, employees, governments, financial institutions and the public for the sake of economic decision making. The quality of decision making is influenced by the quality of financial statement disclosures provided through annual reports. So that the disclosure of information in financial statements can be understood and does not cause misinterpretation, the presentation of financial statements must be accompanied by adequate disclosure 
This study refers to several previous studies including [3-5], which highlights the problem of financial statement disclosure. Disclosure in this study is mandatory disclosure (Mandatory Disclosure). The results of previous studies on the level of disclosure of local government financial statements (LKPD) conducted both at home and abroad still show different results [6-11] so further research is needed to test the inconsistency of the results of the study.

\section{Foundation of theory and development of hypotheses}

2.1 Effect of Regional Wealth (PAD) on the Level of Disclosure of Financial Statements. The wealth of a Regional Government is positively related to increased disclosure because it gives a signal about the quality of regional heads, where regional heads can benefit by increasing their chances of re-election and reducing the cost of interests. From this description, the hypothesis for this research is:

HA1 = Regional wealth (PAD) has a positive effect on the level of LKPD disclosure.

\subsection{Effect of Dependency Level on Report Disclosure Level}

Transfer Funds in Regional Government Finances is a type of regional funding originating from the central or provincial government. Therefore, the central or provincial government will ask for more disclosure in an effort to monitor the performance of local governments on the use of these funds. From this description, the hypothesis for this research is

HA2 $=$ The level of regional dependence has a positive effect on the level of LKPD disclosure.

\subsection{Effect of Age of Local Government (AGE) on the Level of Disclosure of Regional Government Financial Statements}

states that a long-standing organization is considered to have a good ability to disclose information in financial statements in accordance with applicable standards compared to newly established organizations, because the organization does not have a "track record" so little information was disclosed. Based on the description, the research hypothesis is:

HA3 = The age of the regional government has a positive effect on the level of LKPD disclosure

\subsection{The Effect of OPD Amount on Disclosure Level of Regional Government Financial Statements}

Research conducted by Patrick (2007) found that Local Governments in Pennsylvania who have a higher level of functional differentiation will tend to adopt Governmental Accounting Standards Board (GASB) 34 more than local governments with low functional differentiation levels. The more functional differentiation in local government the more ideas, information, and innovations available regarding disclosure [12]. From this description, the hypotheses for this research is:

HA4 = Number of SKPD has a positive effect on the level of LKPD disclosure

\subsection{The Effect of Legislative Measures on the Level of Disclosure of Regional Government Financial Statements}

The DPRD is a regional people's representative body whose job is to oversee the regional government so that it can manage the existing budget to be used properly. In this case, DPRD 
members act as principals and local governments act as stewards. Supervision is carried out by members of the legislature (principal) in an effort to local government (steward) carry out the tasks that have been given. From the description, the research hypothesis is:

HA5 = Legislative size has a positive effect on the level of LKPD disclosure

\subsection{The Effect of Audit Opinion on the Level of Disclosure of Regional Government Financial Statements}

Audit opinions can be a benchmark (indicator) to assess the accountability of a government entity. This opinion can increase or decrease the level of stakeholder confidence in the reporting presented by the auditee, in this case the local government entity. Good financial performance will have an impact on the disclosure of financial statements. From this description, a hypothesis can be developed:

HA6 = Audit opinion has a positive effect on the level of LKPD disclosure

\section{Research method}

This research is a case study in the local government of Kupang City and Kupang Regency with a focus on Disclosure of Regional Government Financial Statements. The data in this study consisted of primary data and secondary data.

\subsection{Research variables}

This study will examine 6 (six) independent variables, namely: Regional Wealth / PAD, Dependency Level, Age of Local Government, Number of OPD, Legislative Size, Audit Opinion of BPK, while one dependent variable is Disclosure of Regional Government Financial Statements. Regional wealth variable is calculated from the total Regional Original Revenue. The level of Dependency is calculated from the General Allocation Fund (DAU) compared to total revenue. For the age of the region, the age of the regional government is used based on the anniversary of the region concerned. The amount of OPD is measured using the total of all OPDs contained in an area. The legislative size variable is measured by the number of DPRD members. The audit opinion, which is used in this study, refers to Hilmi's (2010) research by using the number of audit findings by the BPK on the non-compliance of local governments with applicable laws and regulations.

\subsection{Population and Sample}

This study uses population of local government financial reports in the Province of NTT, especially on the mainland of Timor Island, both Regency and City Government, with the 2014-2018 fiscal year and has been examined by the Supreme Audit Board. The number of regional governments in NTT is 6 Regional Governments consisting of one city government, and five district governments. The sampling technique used is through a non probability sampling approach, namely purposive sampling [13]. The criteria used in selecting the sample of this study are:

1. Regency/City Local Government Financial Reports (LKPD) in NTT Province for the 20142018 period audited by BPK.

2. The Regional Government Financial Report has complete data and is needed in the research process, namely: 
a. Provides data in the form of the main components of the Regional Government's financial statements, namely the Budget Realization Report, Balance Sheet, Cash Flow Report, and Notes to Financial Statements.

b. The financial statements still refer to PP No. 71 of 2010 Appendix II.

\subsection{Analysis Techniques}

All hypotheses in this study will be tested using multiple regression.

The regression equation model is as follows:

Where:

$$
\mathrm{Y}=\alpha+\beta 1 . \mathrm{X} 1+\beta 2 . \mathrm{X} 2+\beta 3 . \mathrm{X} 3+\beta 4 . \mathrm{X} 4+\beta 5 . \mathrm{X} 5+\beta 6 . \mathrm{X} 6+\mathrm{e}
$$

$\mathrm{Y}=$ Disclosure of Regional Government Financial Statements

$\alpha=$ Constant

$\beta 1-\beta 6=$ Regression coefficient X1-X6

$\mathrm{X} 1=$ Regional Wealth $(\mathrm{PAD})$

$\mathrm{X} 2=$ Dependency Level

$\mathrm{X} 3=$ Government Age

$\mathrm{X} 4=$ Number of OPD

$\mathrm{X} 5$ = Legislative Size

$\mathrm{X} 6=$ Audit Opinion

$\mathrm{e}=$ error term

\section{Results and discussion}

From 6 LKPD in NTT Province (Mainland Timor), only 2 LKPD met the criteria every year, so that the total sample was 10 , for 5 years of observation (2014-2018).

Table 1.

Sample Selection Results

\begin{tabular}{lc}
\hline \multicolumn{1}{c}{ Remarks } & Amount \\
\hline $\begin{array}{l}\text { Provincial / Regency / City LKPD in Central Java Province 2014-2018 } \\
\text { period which has been audited by BPK. }\end{array}$ & 6 \\
& \\
$\begin{array}{l}\text { Does not provide data in the form of the main components of the } \\
\text { Regional Government's financial statements, namely the Budget } \\
\text { Realization Report, Balance Sheet, Cash Flow Report, and Notes to }\end{array}$ & 0 \\
$\begin{array}{l}\text { Financial Statements. } \\
\text { The financial statements do not refer to PP Number 71 Year 2010 }\end{array}$ & 4 \\
\hline Attachment II. & 2 \\
\hline
\end{tabular}

Source: Data processed, 2019

\subsection{Hypothesis Testing Results}


The results of the first hypothesis testing indicate that the PAD variable does not affect the level of LKPD disclosure in the city of Kupang and Kupang Regency in the 2014-2018 period, with a significant value of 0.70 . So the first hypothesis cannot be accepted (rejected). These results are similar to [14]. But these results are different from the results of [15]. The PAD variable is insignificant as a result of the low level of public concern over taxes and user fees paid. From the results of the second hypothesis test, it was stated that the level of dependence affected the level of LKPD disclosure so that the second hypothesis was accepted with a significant value of 0.01 . However, the effect is negative, meaning that the level of disclosure of the financial statements of the provincial government does not depend on the amount of the General Allocation Fund received by each region. The results of testing the third hypothesis can not be accepted (rejected) with a significant value of 0.40 . Negative results indicate that the younger the age of an area, the better the level of disclosure, but this does not occur significantly as a result of age does not motivate and encourage a greater level of disclosure of an area.

These results are similar to [16]. The age of regions that are relatively young and tend to be said to have more qualified civil servant personnel with many young ages, does not then produce better disclosure than regions that have long been established. The results of testing the hypotheses four were rejected with a significant value of 0.09 . These results are similar to [17]. The existence of a significant negative relationship means the less the number of OPDs, the higher the level of disclosure. This means that with a small number of OPDs the complexity decreases which results in an increased level of disclosure. The results of testing the hypothesis five, namely the size of the legislature has an influence on the disclosure of financial statements rejected with a significant value of 0.06 . The large number of corruption cases committed by DPRD members also contributed to the reasons for the decline in government performance which subsequently had an impact on the decline in performance on the level of financial statement disclosure. The results of testing hypothesis six were also rejected with a significant value of 0.81 . The audit findings variable is negatively related and not significant to the level of LKPD disclosure. A negative but significant relationship was found in the research of [18] and [19] which links the BPK audit findings to government performance. Negative results state that the fewer audit findings the better the level of disclosure, meaning that with a small number of violations committed by the local government, the level of disclosure committed is higher than that of regions with large violations (many audit findings).

Table 2. Hypothesis Testing Results

\begin{tabular}{|c|c|c|l|}
\hline HA & Coefficient & p-value & \multicolumn{1}{|c|}{ Results } \\
\hline HA1 & 0,73 & $\left.0,70^{*}\right)$ & Rejected \\
\hline HA2 & 6,67 & $\left.0,01^{*}\right)$ & Be accepted \\
\hline HA3 & $-0,00$ & $\left.0,40^{*}\right)$ & Rejected \\
\hline HA4 & $-0,08$ & $\left.0,09^{*}\right)$ & Rejected \\
\hline HA5 & $-16,10$ & $\left.0,06^{*}\right)$ & Rejected \\
\hline HA6 & $-0,02$ & $\left.0,81^{*}\right)$ & Rejected \\
\hline
\end{tabular}

Notes: *) significant at the level $5 \%(0,05)$ 


\section{$5 \quad$ Closing}

Of the 6 hypotheses proposed, namely PAD, Dependency Level, Government Age, Total OPD, Legislative Size, and BPK Audit Opinion, only 1 variable is acceptable, namely Dependency Level. In other words, only 1 variable indicates a significant influence with a significant value of 0.01 .

This study has several limitations. First, this study only uses data for 5 years with 10 observations per year, so that the model experiences some problems in testing data. Second, this study uses a disclosure index that is considered to have the same important weight. Third, in this study, it only explains a small part of the factors that influence the level of disclosure. There are still other factors that can explain the level of disclosure of local government financial statements that were not included in this study because of limited time and data. From these limitations, the advice given is for further research is expected to be able to use the latest data on local government financial reports with a longer observation time with a higher number of local governments, so that more visible developments in the level of disclosure and comparison between local governments, at the same time can reduce problems when processing data.

\section{References}

[1] Republik Indonesia. Undang-Undang Nomor 17 Tahun 2003 tentang Keuangan Negara. Jakarta. 2003

[2] Republik Indonesia. Peraturan Pemerinrah Nomor 71 Tahun 2010 tentang Standar Akuntansi Pemerintah. 2010.

[3] Hilmi, Amiruddin Zul. "Analisis Faktor-Faktor yang Mempengaruhi Tingkat Pengungkapan Laporan Keuangan Pemerintah Provinsi”. Jurnal ASPAK No. 17 Universitas Indonesia. 2010

[4] Khasanah, Nur Lilatul \& Raharjo Siddiq Nur. "Pengaruh Karakterisitik, Kompleksitas, dan Temuan Audit terhadap Tingkat Pengungkapan Laporan Keuangan”. Diponegoro Jurnal Of Accounting. Vol.3 No.3. Hal 1-11. Tahun 2014.

[5] Masdiantini, Putu Riesty \& Erawati, Ni Made Adi. Pengaruh Ukuran Pemerintah Daerah, Kemakmuran, Intergovernment Revenue, Temuan dan Opini Audit BPK pada Kinerja Keuangan. E-Jurnal Akuntansi. Universitas Udayana. 14.2. Februari. 2014

[6] Patrick, Patricia A. 2007. The determinants of organizational innovativeness: The Adoption of GASB 34 in Pennsylvania local government. Ph.D. Dissertation. The Pennsylvania State University, United States-Pennsylvania.

[7] Liestiani, Annisa. 2008. "Pengungkapan LKPD Kabupaten/Kota di Indonesia untuk Tahun Anggaran 2006". Skripsi Sarjana. FEUI. Depok.

[8] Lesmana, Sigit I. 2010. "Pengaruh Karakteristik Pemerintah Daerah Terhadap Tingkat Pengungkapan Wajib di Indonesia". Thesis, Fakultas Ekonomi Universitas Sebelas Maret, Surakarta.

[9] Yulianingtyas, Rena Rukmita., Suhardjanto, Djoko. 2011. „Pengaruh Karakteristik Pemerintah Daerah terhadap Kepatuhan Pengungkapan Wajib dalam Laporan Keuangan Pemerintah Daerah (Studi Empiris pada Kabupaten/Kota di Indonesia). Jurnal Akuntansi\&Auditing. Volume 8/No.1/November 20011: 1-194. 
[10] Fitri, Sri Adella. 2011. "Analisis Tingkat Pengungkapan Laporan Keuangan Pemerintah Daerah (studi Eksploratif pada Kabupaten/Kota di Sumatera Barat".

[11] Syafitri, Febriyani. 2012. Analisis Pengaruh Karakteristik Pemerintah Daerah terhadap Tingkat Pengungkapan Laporan Keuangan. Skripsi Sarjana. FEUI. Depok.

[12] Mandasari, Putriesti. 2009. Practices of Mandatory Disclosure Compliance in Indonesian Local Government. Tesis Master. Universitas Sebelas Maret.

[13] Sekaran, Uma. 2006. Risearcch Methods for Bussines. Edisi 4 buku 1. Terjemahan Yon, Kwan. Jakarta: PT.Salemba Empat.

[14] Sumarjo, Hendro. 2010. "Pengaruh Karakteristik Pemerintah Terhadap Kinerja Keuangan Pemerintah Daerah. Skripsi Sarjana Fakultas Ekonomi Universitas Sebelas Maret. Surakarta.

[15] Laswad, F., Fisher, R., \& Oyelere, P. 2005. "Determinant of Voluntary Internet Financial Reporting by Local Government Authorities". Journal of Accounting and Public Policy.

[16] Wardani, Puruwita. 2012. Faktor-Faktor yang Mempengaruhi Luas Pengungkapan Sukarela. Jurnal Akuntansi Dan Keuangan, Vol. 14, No. 1, Mei 2012: 1-15

[17] Hendriyani, Ririn dan Tahar, Afrizal. Analisis Faktor-Faktor Yang Memengaruhi Tingkat Pengungkapan Laporan Keuangan Pemerintah Provinsi Di Indonesia. Jurnal Bisnis dan Ekonomi (JBE), Vo.22 No.1. Maret 2015, Hal. 25- 33. 2015

[18] Sudarsana, Hafidh Susila. 2013. "Pengaruh Karakteristik Pemerintah Daerah dan Temuan Audit BPK terhadap Kinerja Pemerintah Daerah (Studi Pada

[19] Marfiana, N., dan Kurniasih L. 2011. Pengaruh Karakteristik Pemerintah Daerah dan Hasil Pemeriksaan Audit BPK terhadap Kinerja Keuangan Pemerintah Daerah Kabupaten/Kota. Fakultas Ekonomi Universitas Sebelas Maret. 